\title{
AGAMA SIPIL DI AMERIKA SERIKAT: TELAAH TERHADAP GAGASAN DAN PERAN ROBERT N. BELLAH
}

\author{
Ahmad Sahidah \\ Program Pascasarjana, Universitas Nurul Jadid, Paiton, Probolinggo
}

ahmadsahidah@unuja.ac.id

\begin{abstract}
This article will unravel the emergence of civil religion in the United States that cannot be separated from America's long history, since the civil war, the declaration of independence and the influence of enlightenment and Christian values (especially Protestantism) that are deeply embedded in the American people. He was born as a recognition of the highest values, not one of the denominations of Christianity itself. At the same time, as a criticism of the use of religious symbols in official state practice. With the hermeneutic reading of Bellah's works, it can be concluded that civil religion is inevitable, because each group has a religious dimension. To say that there is no civil religion, is to say that the civitas, the civil order itself does not exist, it should not appear. Each group produces communal symbols and rituals that give instructions and tie them together. Thus, civil religion does not only belong to America, it can belong to other nations in the world.
\end{abstract}

Keywords: civil religion, symbols, church, state, and politics

\begin{abstract}
Abstrak
Artikel ini akan mengurai kemunculan agama sipil di Amerika Serikat yang tidak bisa dilepaskan dari sejarah panjang Amerika, sejak perang sipil, deklarasi kemerdekaan dan pengaruh pencerahan serta nilai-nilai Kristiani (terutama Protestantisme) yang tertanam kuat di dalam diri bangsa Amerika. Ia lahir sebagai pengakuan terhadap nilai tertinggi bukan salah satu denominasi dari agama Kristen sendiri. Sekaligus, sebagai kritik terhadap penggunaan simbol keagamaan dalam praktik resmi kenegaraan. Dengan pembacaan hermeneutik terhadap karya-karya Bellah, dapat disimpulkan bahwa agama sipil adalah tak terelakkan, karena setiap kelompok mempunyai dimensi religius. Mengatakan agama sipil tidak ada, sama saja dengan mengatakan bahwa civitas, tatanan sipil itu sendiri tidak ada, seharusnya tidak muncul. Setiap kelompok menghasilkan simbol-simbol dan ritual komunal yang memberikan petunjuk dan mengikatnya bersama. Dengan demikian, agama sipil tidak hanya menjadi milik Amerika, ia bisa menjadi milik bangsa lain di dunia.
\end{abstract}

Kata Kunci: agama sipil, simbol, gereja, negara, dan politik 


\section{PENDAHULUAN}

Persoalan agama sebagai realitas manusiawi tak terelakkan telah menyusup pada hampir semua ranah kehidupan. Ia telah memasuki segala lapisan masyarakat dengan berbagai bentuk. Keanekaragaman ekspresi ini tidak lepas dari cara memandang dan menafsirkan agama sebagai institusi dan nilai-nilai, fenomena sejarah dan ajaran normatif. Tidak jarang, perbedaan ini memperdalam jurang pemahaman yang juga mempunyai implikasi terhadap sikap sosial, politik dan kebudayaan mereka. Perpecahan internal maupun eksternal kelompok keagamaan selalu mewarnai perjalanan institusi itu sendiri.

Dalam sejarah panjangnya, agama telah menjadi inspirasi bagi kemajuan peradaban manusia dan sekaligus menjadi pemicu bagi munculnya kehancuran tatanan masyarakat dengan berbagai alasannya. Tentu saja, tidak bisa dilupakan begitu saja perang agama, meskipun banyak orang yang mengingkarinya. Namun sejarah telah mencatat bahwa dalam sejarah manusia perang salib (perang Muslim dan Kristen) ${ }^{1}$ telah meninggalkan trauma kemanusiaan hingga sekarang, untuk menyebut sebagian contoh. Bahkan trauma ini turut mendorong kembali terjadinya perang agama yang terjadi di banyak negara. Tidak hanya kaum Muslim dan Kristen yang menyimpan potensi konflik, tetapi juga penganut agama-agama lain, karena dalam sejarahnya dari setiap agama selalu muncul apa yang disebut dengan kelompok fundamentalis ${ }^{2}$

\footnotetext{
${ }^{1}$ Untuk uraian kritis tentang perang ini, lihat Karen Amstrong, Fields of Blood: Religion and the History of Violence (London: The Bodley Head, 2014).

${ }^{2}$ Seharusnya seseorang yang memegang teguh komitmen religius harus mendasarkan pada sebuah ajaran keagamaan
}

yang mengedepankan praktik-praktik pemaksaan dalam membangun tatanan masyarakat yang diidealkan.

Selain itu media cetak dan elektronik telah memberitakan konflik-konflik ini secara teratur, seperti benturan-benturan yang mematikan atau pertikaian yang melibatkan orang Hindu dan Muslim di India atau orang Buddha di Srilanka. Tema-temanya berkenaan dengan pendeta akademik Jesuit dan para militer di El Salvador, gerilyawan Islam dan komunis di Afghanistan, cabang-cabang Islam yang beranekaragam di Iraq ataus Syria, dan orang Kristen dan Muslim di Nigeria dan di tempat lain di Afrika. ${ }^{3}$ Tambahan lagi, konflik Kristen dan Katolik di Irlandia yang turut menggugat pesan damai keagamaan itu sendiri.

Sementara, pemahaman terhadap agama mempunyai pengaruh luar biasa terhadap tindakan manusia. Dalam sejarahnya, sejak abad kesembilan belas ada sebuah kecenderungan yang sama di dalam studi agama untuk meletakkan agama dan akalbudi secara berseberangan satu sama lain. Rasionalitas ${ }^{4}$, yang dirumuskan dalam pengertian luasnya sebagai pemahaman objektif dan kontrol terhadap realitas, berbeda dengan agama, yang dicirikan sebagai sebuah fenomena pra-rasional, tidak-rasional

\footnotetext{
yang mutlak dan murni yang kemudian disebut sebagai fundamentalis. Sebenarnya istilah ini berasal tradisi AngloSaxon, yang secara khusus diterapkan pada orang-orang, seperti Protestan dan Muslim yang menyatakan bahwa Injil dan al-Qur'an atau kitab-kitab suci lain harus diterima dan ditafsirkan secara harfiah. Lihat Jeff Hayness, Religion in Third World Politics (Buckingham: Open University Press, 1993). Lihat juga Margaret R. Miles tentang pengeritan fundamentalisme praktis dalam Seeing and Believing: Religion and Values in The Movies (Boston: Beacon Press, 1993), hlm. 94.

${ }^{3}$ Uraian lebih lanjut tentang hal ini bisa dibaca di Jeff Hayness, Religion in Third World Politic (Buckingham: Open University Press, 1993), hlm. 1.

${ }^{4}$ Rasionalitas dan objektivitas disebut Walter Lippmann sebagai aspek kebudayaan Barat yang abadi. Dikutip dari Peter Levine, Nietzsche: Krisis Manusia Modern, terj. Ahmad Sahidah (Jogjakarta: Ircisod, 2001), hlm. 1.
} 
atau bahkan anti-rasional. Hal ini, bisa dilihat dari keyakinan positivis awal yang memandang agama sebagai sebuah usaha mendasar untuk mengontrol alam, tetapi ia telah ditakdirkan untuk digantikan oleh metode rasional ilmu pengetahuan. Ludwig Feuerbach, Karl Marx dan Sigmund Freud menyergah lebih keras bahwa bagi mereka agama adalah sebuah tipu-daya, sebuah distorsi yang sangat tidak rasional dan berbahaya terhadap realitas, dan penghapusan agama menempati peringkat teratas bagi semua agenda mereka untuk kemajuan manusia rasional. ${ }^{5}$

Antitesis terhadap agama bertolak dari kritik keras yang diajukan kepada institusi ini karena ketidakmampuannya untuk menciptakan keadaan lebih baik, terlepas dari sumbangan agama terhadap kemajuan manusia. Bahkan Marx menyebut kritik terhadap agama adalah prasyarat bagi setiap kritik, yang menyebabkan tersebarnya skeptisisme terhadap agama dan pengaruhpengaruhnya. ${ }^{6}$ Tentu, pandangan penulis Das Capital ini tidak bisa dilepaskan dari fondasi kebenaran yang menjadi pijakan pemikirannya, yaitu dialektika materialisme. ${ }^{7}$

\footnotetext{
${ }^{5}$ Dikutip dari Ronald M. Green, Religious Reason: The Rational and Moral Basis of Religious Belief (New York: Oxford University Press, 1978), hlm. 3. Untuk representasi pernyataan-pernyataan positivis, lihat August Comte, Cour de philosophie positive, 6 vol. (Paris: Barchelier, 1830-1842), dan Edward Tylor, Primitive Culture, edisi ke-2, 2 vol. (London: John Murray, 1873). Pandangan Feuerbach dijelaskan secara panjang lebar di dalam bukunya The Essence of Religion, terj. George Eliot (New York: Harper and Bros., 1957). Pemikiran Freud bisa dibaca di dalam tulisannya Totem and Taboo, terj. James Stranchey (New York: W. W. Nroton \& Co., 1950) dan The Future of an Illusion, terj. W. D. Rovson-Scott, edisi revisi (Garden City, N. Y.: Doubleday \& Co., 1964). Karl Marx and Friedrich Engels on Religion (New York: Schoken Book, 1964) mengumpulkan banyak pernyataan terpisah dari kedua pemikir ini mengenai persoalan di atas.

${ }^{6}$ Dikutip dari Margaret R. Miles, op.cit., hlm. 12.

${ }^{7}$ Gagasan-gagasan Marx bisa dirujuk pada karya yang bisa diakses oleh khalayak, sehingga ide-idenya tidak lagi
}

Selanjutnya, cara lain untuk menegaskan hakikat spiritual adalah dengan mengatakan bahwa kita adalah binatang religius dengan sebuah kecenderungan yang tetap untuk mengalami yang alamiah dalam pengertian supra-natural. Antropolog R. R. Marett untuk pertama kali menegaskan bahwa homo sapiens lebih baik disebut dengan homo religiosus. ${ }^{8}$ Bagi antropolog lain seperti Clyde Kluckhohn, bahwa tidak ada kelompok manusia tanpa agama; dan memang, dalam sebuah analisis 'keserupaan keluarga' (Family resemblance) terhadap konsep agama, masyarakat komunis juga mempunyai aspek-aspek religiusnya sendiri. Sejarawan agama besar Mircea Eliade mengemukakan sebuah pandangan yang diterima umum ketika dia mengatakan bahwa "yang suci" adalah sebuah unsur di dalam struktur kesadaran dan bukan sebuah tahap dalam sejarah kesadaran. ${ }^{10}$ Rudolf Otto bahkan mengatakan bahwa ide tentang yang suci adalah a priori, batiniah dalam akal manusia. ${ }^{11}$

Menurut beberapa antropolog ada banyak tanda-tanda kepedulian religius

dianggap sebagai karya abstrak dan rumit, seperti penjelasan John Farndon dalam The World's Greatest Idea (London: Icon Books, 2011), hlm. 156-163. Marx menegaskan bahwa pikiran seseorang tidak terpisah dari materi (matter) dan dunia benda membentuk pemikiran manusia. Orang-orang mengalami keterasingan karena kepercayaan yang berlaku di dalam masyarakat yang dianggap dasar dari hakikat manusia, yang justru melayani kepentingan kelas dominan, contohnya agama yang diinstitusikan. Lembaga ini telah turut menjadi pembenaran bagi kedudukan buruh dan konsumen yang ditindas.

${ }^{8}$ R. R. Marett, Sacraments of Simple Folks (Oxford: Clarendon Press, 1932), hlm. 3.

${ }^{9}$ Clyde Kluckhohn, Preface to William Lessa and Evon Vogt, Reader in Comparative Religion (New York: Harper and Row, 1979) hlm. v.

${ }^{10}$ Mircea Eliade, A History of Religious Ideas, Vol. I, terj. Willard Trask (Chicago dan London: Chicago University Press,1978), hlm. xii.

${ }^{11}$ Rudolf Otto, The Idea of the Holy, terj. John Harvey (New York: Oxford University Press, 1958), bab 14-20. 
di dalam bukti-bukti awal dari prilaku manusia. Sejauh kita bisa melacak ke belakang bukti-bukti itu kita menemukan bahwa manusia telah mengerjakan sesuatu yang tidak dikerjakan oleh spesies lain. Mereka menguburkan atau sebaliknya dengan sengaja membuang mayat dari jenis mereka sendiri. Suku Neandearthal, seratus ribu tahun yang lalu, menempatkan makanan dan batu api yang bernilai tinggi di kuburan mereka. Manakala, suku Cro-Magnon dua puluh lima ribu tahun yang lalu menguburkan senjata, ornamen dan makanan dengan orang yang meninggal di antara mereka dan terkadang hartal merah yang berdebu - di atas mayat atau kuburankuburan mereka. Praktik-praktik ini jelas mengungkapkan beberapa gagasan tentang kehidupan setelah mati, dan kepercayaan semacam ini kemudian menggumpal menjadi kepercayaan yang terbentuk secara sadar, sebuah ekspresi yang masih hidup paling awal dari manusia sebagai binatang religius. Tidak pelak, banyak tradisi dalam masyarakat kita yang memperlakukan manusia yang meninggal dunia dengan penuh perhatian sebagai tanda bahwa mereka akan menjalani kehidupan yang lain.

Dengan demikian, pemahaman terhadap agama perlu direkonstruksi kembali untuk memperoleh pemahaman yang utuh dalam usaha menghindari penyalahgunaan otoritas agama untuk kepentingan manusia itu sendiri. Tentu saja, pendekatan yang digunakan secara ideal mengacu pada berbagai disiplin. Untuk itu, sumbangan Robert N. Bellah bisa digunakan untuk mengkayakan pemahaman keagamaan sebagai ikhtiar untuk mengelak dari pengertian agama yang sempit, picik dan tendensius. Pada waktu yang sama, gagasan agama sipil adalah ide yang juga perlu ditimbang untuk menempatkan agama dalam kehidupan kebangsaan.

\section{AGAMA DAN POLITIK DI AMERIKA SERIKAT}

Bellah mengatakan bahwa subjudul di atas tersebut tampak aneh bagi pembaca. Di dalam konstitusi ditegaskan pemisahan gereja dan negara, dan agama dianggap sebagai persoalan pribadi. Sebenarnya cara berpikir ini mewakili sebuah kerancuan berkelanjutan tentang kata "publik." Acapkali di Amerika kami membedakan antara sektor publik dan pribadi, yang pertama pemerintah dan yang kedua bukan. Tetapi di dalam dua pengertian ini agama, paling tidak agama Biblikal, di mana keanekaragaman bentuknya membentuk tradisi agama utama di Amerika, tidak bisa menjadi persoalan pribadi ${ }^{12}$. Di sini, dia mengajukan dua alasan: Pertama, orangorang Kristen dan Yahudi mengakui satu Tuhan yang menciptakan surga dan bumi, semua yang terlihat dan tidak, yang kekuasannya jelas tidak hanya melampaui kehidupan pribadi tetapi bangsa itu sendiri. Tidak ada ranah pribadi atau publik yang tidak menjadi perhatian sebuah tradisi religius semacam ini.

Kedua, di dalam salah hal penting, "publik" tidak berarti pemerintahan tetapi sebuah istilah yang bertentangan dengannya. Pada transformasi demokratik abad kedelapan belas, "publik" berarti kewarganegaraan yang mencerminkan perhatian bersama, pembebasan, danmemilih wakil-wakilnya untuk membentuk pemerintahan, yang

${ }^{12}$ Robert N. Bellah (et.al.), The Good Society (New York: Vintage Books, 1992), hlm. 179. 
kekuasaannya dibatasi oleh sebuah konstitusi. ${ }^{13}$ Badan-badan keagamaan lebih mencerminkan makna publik ini, bukan karena ditegaskan oleh pemerintah dengan keistimewan hukum tetapi karena ia memasuki pembahasan bersama tentang kebaikan publik. Di dalam pengertian inilah seseorang sah membicarakan "gereja publik'. Bahkan klausa "tindakanbebas" dari Amandemen Pertama Konstitusi menjamin hak badanbadan keagamaan. ${ }^{14}$ Gagasan tentang gereja publik sebenarnya menunjukkan partisipasi dan akses masyarakat yang lebih luas terhadap penafsiran kitab suci dan gereja, yang sebelumnya menjadi monopoli para pendeta.

Para pendiri republik Amerika jelas cenderung pada agama publik di dalam pengertian terakhir. Mereka percaya bahwa kepercayaan agama memberikan sumbangan yang esensial bagi pembentukan kewarganegaraan yang bertanggung jawab yang mampu mempertahankan sebuah republik demokratis. Bellah mengutip pidato John Adams ketika berpidato pada tahun pertama, "Konstitusi kita dibuat untuk sebuah masyarakat yang bermoral dan beragama. Sepenuhnya ia berbeda dengan pemerintahan yang lain. ${ }^{15}$

Lebih jauh, Bellah masih melihat peran yang dimainkan agama di dalam kehidupan sosio-budaya dan politik

\footnotetext{
${ }^{13}$ Ibid., hlm. 179.

${ }^{14}$ Ibid., hlm. 179-180. Tentang agama publik bisa dibaca buku José Casanova, Public Religions in the Modern World (Chicago dan London: The University of Chicago Press, 1994). Di sini Casanova menjelaskan perbedaan agama privat dan publik, yang mengutip Mary Douglas bahwa pembedaan biner sebagai prosedur analitik tidak menjamin bahwa eksistensinya memang seperti itu. Lanjut Douglas, kita harus curiga pada seseorang yang menyatakan bahwa ada dua jenis masyarakt, dua jenis realitas atau proses. Istilah pertama juga disebut keagamaan individual dan kelompok.

${ }^{15}$ Bellah, op.cit., hlm. 180.
}

Amerika Serikat, ${ }^{16}$ di antaranya: Pertama, bagi penganut agama, kesetiaan religius melampaui kesetiaan nasional. Hal ini tidak berarti bahwa kesetiaan ini dengan sendirinya pasti berlawanan; tetapi ketika keduanya bertentangan, maka klaim agama didahulukan. Keduanya memang pernah berlawanan di Amerika dan ini adalah bukti dari sejarah penolakan dan pembangkangan sipil, tetapi semua komunitas agama besar menerima republik Amerika dan mengutamakan kearifan dari konflik, yang terakhir sebagai sebuah usahan terakhir setelah gagal diperoleh kesaksian dan kompromi. Orang-orang beriman mempunyaisebuah kesetiaan bersyarat pada negara tetapi sebuah kesetiaan tak bersyarat kepada Tuhan, inilah alasan yang menggerakkan mereka untuk merespons kebutuhan manusia dengan cinta melampaui permainan relativistik kepentingan individu, kelompok atau bangsa. Di dalam hal tertentu, hal ini memberikan mereka sebuah kesempatan lebih besar untuk mengangkat isu-isu - tentang perdamaian, ekologi global, kemiskinan di dunia ketiga - dibandingkan jika kesetiaan mereka murni bersifat kebangsaan. Tentu saja, banyak orangorang sekuler juga mempunyai kesetian dan kewajiban lintas bangsa. Sehingga hal ini tidak hanya menjadi milik agama, dan bahkan justru orang-orang religius secara konvensional tidak mempunyai kepedulian seperti yang tersebut di atas.

Kedua, orang-orang di dalam kongregasi religius yang terorganisir turut serta, di dalam jumlah yang lebih besar dan banyak meluangkan waktu dan uang daripada kelompok-kelompok

\footnotetext{
${ }^{16}$ Bellah, The Good Society, hlm. 217-218.
} 
lain di Amerika Serikat, di dalam komunitas-komunitas yang melampaui keluarga dan lingkaran sahabat formalnya. Bagi Mel Reese lokalisme dari sebuah kongregasi bisa menjadi sebuah masalah, sejenis egoisme kelompok, yang mengabaikan masyarakat yang lebih besar. Bagi Robert Cooper dan Thomas Raskin jemaah gereja mempertahankan tidak hanya orang-orang beriman tetapi warga negara lebih baik daripada jika mereka terisolasi sebagai individu dan kelompok. Kongregasi seringkali menjauh dari kongregasi yang lain di lingkungan sekitar mereka, dan bahkan dari denominasinya sendiri; tetapi ketika mereka berkumpul mereka bisa menjadikan sebuah perbedaan besar ini di dalam kualitas kehidupan komunitas.

Ketiga, dengan adanya ketegangan antara kongregasi lokal dan organisasi para-gereja, yang memperlemah kemampuan mereka untuk melakukan missi mereka secara efektif, adalah mungkin untuk membayangkan seperangkat lembaga-lembaga perantara, yang melintasi batas-batas denominasional, yang mengantarkan klerus dan orang awam bersamasama membahas isu-isu teologis dan sosial tentang akar dari ketegangan ini. Institusi-institusi ini bisa berbentuk Akademi-akademi Evangelisnya Eropa di mana mereka memberi perhatian pada pendidikan dan pembahasan dibandingkan tindakan langsung. Mereka bisa memajukan sofistifikasi teologis dan sosiologi, tetapi tujuannya untuk meningkatkan kehidupan ibadah dan iman.

Dewasa ini banyak sekolah ketuhanan dari berbagai denominasi yang mengusahakan sesuatu semacam ini untuk sampai pada orang awam. Tetapi kelompok akademi awam yang lebih kuat bisa banyak melakukan untuk mengatasi kecurigaan antara struktur kongregasi dan denominasional melalui pembaharuan terhadap anugerah biblikal dan teologis yang merupakan sumber dasar mereka. Di dalam usaha untuk mengembalikan dan memperkuat jalan pemikiran yang kosong, akademiakademi ini bisa membantu memberikan suara lebih terpelajar dan jelas untuk gereja publik. Akademi-akademi semacam ini juga bisa memberikan sumbangan pada pencarian kebaikan bersama hanya di dalam hal bahwa mereka memahami dan menghormati komunitas iman yang berbeda di dalam masyarakat dan dunia yang pluralistik.

Terakhir adalah banyak institusi yang kuat yang mempengaruhi kehidupan kita dan banyak menghabiskan energi - ekonomi, pemerintah dan pendidikan yang merusak kehidupan kita, menekan kita untuk bersaing meraih keuntungan individual bukan untuk menggabungkan kesejahteraan bersama (common welfare), dan mereka tidak memberikan kita akan makna kehidupan ketika mereka menganggap keberadaan kita sebagai sekelompok orang yang bersaing demi uang, kekuasaan, prestise atau barang-barang yang menjadi simbol dari mereka. Komunitas agama tidak hanya memberikan kita keanggotan dan pengakuan. Mereka juga membantu kita berjuang menghadapi masalah makna tertinggi, atau mencoba menemukan jalan untuk hidup berdasarkan sesuatu yang tidak sekedar perhitungan untungrugi atau nafsu; apakah kita mempunyai sebuah tempat di semesta ini dan sebuah 
tujuan yang kita cari di sini. ${ }^{17}$ Hubungan antara agama dan politik memang telah berakar mendalam di dalam sejarah Kristen.

\section{PERAN ROBERT N. BELLAH DI AMERIKA SERIKAT}

Di negara Paman Sam ini, kebebasan dijamin oleh konstitusi, sehingga atmosfir intelektual dan keilmuan berkembang baik. Di sinilah, Bellah mengapresiasikan perhatian intelektualnya, meskipun tidak jarang mendapat kritik keras dari koleganya. Tak dapat dinafikan, Amerika telah menjadi rumah bagi banyak intelektual dunia yang berhijrah dari negara asalnya, seperti Herbert Marcuse, Jean Paul Sartre, dan Martin Heidegger.

Peran yang dimainkan Bellah sangat penting bagi pengembangan kehidupan masyarakat di Amerika Serikat. Tulisan Bellah, Civil Religion in America, yang pada awalnya dipresentasikan di sebuah konferensi di Boston pada tahun 1965 sebagai analisis terhadap pidato pelantikan Presiden Kennedy, ${ }^{18}$ telah menjadi sejarah penting karena esainya mencerminkan pandangan positif terhadap proses Amerika yang ditegaskan secara singkat oleh akademisi liberal. Pandangan-pandangan ini diilhami oleh penegasan Batas-Batas baru dan Masyarakat Baru pada tahuntahun awal John F Kennedy dan Lyndon Johnson, ketika esai ini lahir, iklimnya telah berubah, namun kategorinya masih seperti sebelumnya. ${ }^{19}$

\footnotetext{
${ }^{17}$ Ibid., hlm. 218-219.

${ }^{18}$ Andrew Shanks, Civil Society, Civil Religion (Oxford: Blackwell, 1995), hlm. 5.

${ }^{19}$ Seperti dinyatakan oleh Martin Marty, A Nation of Behavers, Chicago, Illinois.: University of Chicago Press, 1976), hlm. 183.
}

Kritisisme Bellah ditunjukkan dengan penolakannya terhadap perang Amerika melawan Vietnam yang dilihat sebagai pengejawantahan dari nilai-nilai agama sipil Amerika. Andrew Shanks menyebut dia sebagai orang yang bukan nasionalis. ${ }^{20}$ Tentu saja, Bellah melihat perang bukan sebagai jalan keluar untuk menyelesaikan masalah. Sehingga tidak ada pembenaran apapun untuk melakukan invasi pada bangsa lain.

Namun demikian, kiprah Bellah tidak hanya diakui sebagai sosiolog yang kritis, tetapi juga pendidik. Untuk yang terakhir, Bellah pernah mendapat medali penghargaan yang ditandatangai oleh Presiden Amerika William Jefferson Clinton, yang menyatakan:

The President of the United States of America awards this National Humanities Medal to Robert N. Bellah for his efforts to illuminate the importance of community in American society. A distinguished sociologist and educator, he has raised our awareness of the values that are at the core of our democratic institutions and of the dangers of individualism unchecked by social responsibility. ${ }^{21}$

Isi dari pernyataan Presiden makin mengukuhkan kiprah Bellah sebagai pemikir yang berusaha terus-menerus untuk mengingatkan kembali rasa kebersamaan di dalam komunitas dan menggugah kesadaran bangsa Amerika akan nilai-nilai yang merupakan inti dari lembaga-lembaga demokrasi dan bahaya dari individualisme yang tidak tidak dibarengi dengan tanggung jawab sosial.

\footnotetext{
${ }^{20}$ Andrew Sharks, op.cit., hlm. 5.

${ }^{21}$ Diambil dari www. hartsem.ed/robert n. bellah/ autobiography/html. Penghargaan ini diterima pada tanggal 20 Desember 2000.
} 


\section{AGAMA SIPIL DI AMERIKA DAN MASA DEPAN AGAMA}

Pada masa awal berdirinya Amerika, agama mempunyai kedudukan yang sangat penting di dalam superstruktur dan infrastruktur rezim politik baru. Yang pertama terdapat di dalam Deklarasi Kemerdekaan. Bellah mengartikan superstruktur di sini adalah sebuah lokus kedaulatan yang berada di atas kedaulatan negara. Barangkali pengakuan yang paling mencolok terhadap kedaulatan tertinggi ini berasal dari Madison pada tahun 1785 di dalam perdebatan tentang kebebasan agama di Virginia:

It is duty of every man to render to the Creator such homage, and such only, as he believe to be acceptable to him. This duty is precedent both in order of time and degree of obligation, to the claims of Civil Society. Before any man can be considered as a member of Civil Society, he must considered as subject of the Governor of the Universe: and if a member of Civil Society, who enters into any subordinate Association, must always do it with a reservation of his duty to general authority; much more must every man who becomes a member of any particular Civil Society, do it with a saving of his allegiance to the Universal Sovereign." 22

Sebagai salah satu pendiri Amerika, Madison telah meletakkan fondasi bagi negara ini dengan keutamaan nilai-nilai religius di atas nilai-nilai masyarakat sipil. Namun demikian dasar ini tidak mengabaikan perannya di dalam mengatur hubungan sosial dan politik. Deklarasi kemerdekaan itu sendiri menunjuk pada kedaulatan Tuhan di atas

${ }^{22}$ Dikutip dari Bellah, Varieties of Civil Religion, hlm. 10-11. masyarakat politik kolektif itu sendiri dengan merujuk pada pembukaannya yang berbunyi "hukum alam dan Tuhan" yang berada di atas dan menilai hukum manusia.

Berkenaan dengan pentingnya referensi pada kedaulatan suprapolitik, pada Tuhan yang berada di atas bangsa dan yang tujuan-tujuannya menjadi ukuran untuk mempertimbangkan eksistensi bangsa dan bahkan hanya di dalam pengertian inilah dijustifikasikan, menjadi sebuah sifat permanen dari kehidupan politik Amerika untuk selamanya. Menurut Bellah, keberadaan dari simbolisme religius tingkat tertinggi di dalam kehidupan politik republik ini mengukuhkan penegasan bahwa terdapat agama sipil di Amerika, ${ }^{23}$ yang bersifat formal dan namun marginal. Formal artinya di dalam penyebaran dan abstraksi dari prinsip-prinsipnya, meskipun di dalam hal ini sangat dekat dengan agama sipilnya Rousseau. Marginal artinya tidak mendapat dukungan resmi di dalam ranah hukum dan konstitusional. Sekali lagi, Bellah menegaskan bahwa tidak ada rujukan pada tuhan dan agama sipil di dalam konstitusi Amerika Serikat. ${ }^{24}$

Tentang terpinggirkannya agama sipil Amerika, Bellah mengatakan:

The marginality of the American civil religion is closely connected with the liberal side of our heritage and its most important expression, the constitution. This side has lead many to deny there is a civil religion or there ought to be in America. And indeed, from the point of view of the liberal political idea there need not and perhaps ought not to be. The state is a purely neutral legal mechanism without purposes or values.

\footnotetext{
${ }^{23}$ Bellah, Varieties of Civil Religion, hlm. 12.
} 
Its role function is to protect the rights of individuals, that is, to protect freedom. And yet freedom, which would seem to be an irreducible implication of liberalism etymological grounds alone, no matter how negatively and individualistically defines, does imply a purpose and value. Since I believe a pure liberalism is a reductio ad absurdum and a sociological impossibility. I would locate here at least one of the reasons a pure liberal state has never existed and why in America the rhetoric and to some extent the substance of republicanism has always existed in uneasy tandem with liberalism.

Jelas di sini Bellah menolak asumsi kaum liberal bahwa negara itu didasarkan pada mekanisme hukum legal murni tanpa tujuan dan nilai. Fungsi satusatunya hanyalah melindungi hak-hak individual, yaitu melindungi kebebasan. Padahal kebebasan itu tampaknya hanya sebagai sebuah implikasi paling kecil dari liberalisme atas dasar etimologis semata-mata, bukan masalah bagaimana dirumuskannnya secara negatif atau individualistik, ia mempunyai implikasi sebuah tujuan dan nilai. Bagi Bellah tidak pernah ada sebuah negara liberal murni. ${ }^{25}$

Tepatnya, dari sudut pandang republikanisme agama sipil sangat dibutuhkan, sebagai sebuah komunitas politik aktif yang menyertakan warga negara mesti mempunyai sebuah tujuan dan seperangkat nilai-nilai. Kebebasan di dalam tradisi republikan adalah sebuah nilai positif yang menegaskan

\footnotetext{
${ }^{25}$ Ibid., hlm. 12. Hal yang sama dinyatakan dengan nada lain oleh Ludwig Wittgenstein, filsuf Lingkaran Wina, bahwa nilai-nilai adalah persoalan besar, Anda akan gagap membicarakannya sebab nilai-nilai meliputi "kepentingan, kesenangan, kesukaan, pilihan, tugas, kewajiban moral, hasrat, keingingan, kebutuhan, sesuatu yang tidak disukai dan ketertarikan, yang sangat urgen di dalam sebuah masyarakat majemuk. Dikutip dari Martin E. Marty, "The Protestan Experience and Perspective", di dalam Rodger Van Allen, American Religious Values and The Future of America (Philadelphia: Fortress, 1978), hlm. 30.
}

adaya perhargaan dan harkat dari persamaan politik dan pemerintahan yang merakyat. Ia harus menunjukkan etika di dalam pengertian positif dan memunculkan komitmen etik dari warga negaranya. Karena alasan inilah, tegas Bellah, tak terelakkan harus menekankan simbolisasi tatanan eksistensi tertinggi yang ditunjukkan oleh nilai-nilai dan keutamaan republikan. Simbolisasi semacam ini mungkin tidak lebih dari sekedar pemujaan terhadap republik itu sendiri sebagai kebaikan tertinggi, atau jika memang demikian, sebagaimana di dalam kasus Amerika, pemujaan terhadap realitas yang mengukuhkan ukuran-ukuran yang ingin dipenuhi oleh republik ini. ${ }^{26}$

Terciptanya komunitas nasional pertama kali di Amerika, yang sekarang diakui secara luas, didahului oleh revolusi oleh satu atau dua generasi. Ia adalah hasil dari Kebangkitan Besar tahun 1740-an, sebuah gelombang revivalisme religius yang meluas di seluruh koloni dan memberikan mereka untuk pertama kalinya sebuah perasaan solidaritas bersama. ${ }^{27}$ secara historis, emosi keagamaan telah menyuburkan kesadaran untuk mewujudkan kehidupan ideal berdasarkan nilai-nilai.

Rezim liberal tidak pernah menolak agama sipil yang telah tersirat di dalam Deklarasi Kemerdekaan dan bahkan tetap hidup di dalam kehidupan politik meskipun Konstitusi tidak

\footnotetext{
${ }^{26}$ Ibid., hlm. 12-13.

${ }^{27}$ Ibid., hlm. 13. Sebagaimana ditunjukkan oleh Profesor Nathan Hatch, solidaritas religius secara bertahap diberikan sebuah penafsiran lebih politik dari dalam komunitas religius pada tahun 1750-an dan 1760-an dengan munculnya apa yang sebut "milenialisme sipil". Bellah mengatakan bahwa komunitas nasional dengan inspirasi religiusnya yang melahirkan revolusi Amerika dan menciptakan sebuah bangsa baru. Komunitas inilah yang merupakan republik sejati, bukan rezim konstitusional liberal yang muncul pada tahun 1789.
} 
mengungkapkannya. Namun, dari sudut pandang rezim legal, elaborasi lebih jauh terhadap simbolisme agama yang melampaui agama sipil formal dan marginal murni bersifat pribadi. Sedangkandarisudutpandangkomunitas nasional, sebagian besar agama di dalam kritiknya pada dirinya, elaborasi semacam ini adalah bersifat publik meskipun kurang di dalam status legalnya. Di sinilah, kata Bellah dengan mengutip Martin Marty, bisa membicarakan teologi publik, yang berbeda dengan agama sipil. Namun demikian, Bellah tidak mau mengidealisasikannya. ${ }^{28}$

Bellah juga tidak menampik peran agama bagi terciptanya kewarganegaraan. Agama telah berperan di dalam membentuk, memasyarakatkan dan mendidik warga negaranya dengan kepercayaan etik dan spiritual, yang akhirnya terinternalisasikan sebagai nilai utama Republik. Tentu saja, Bellah juga mendapat tantangan dari intelektual lain, misalnya Fenn dengan idenya tentang bangsa Amerika sebagai Israel yang baru. Menurutnya, Bellah bermaksud untuk menggunakan simbol ini tidak lain untuk memperteguh kedudukan penguasa (pemerintah federal) dan mansakralkan badan-badan pemerintah dan hukum di negara itu. ${ }^{29}$

\section{AGAMA SIPIL}

Agama sipil adalah sebuah istilah yang pertama kali digunakan oleh Jean Jacques Rosseau, sejalan dengan maksud Durkheim bahwa pengalaman sosial dan agama adalah mempunyai

\footnotetext{
${ }^{28}$ Ibid., hlm. 14.

${ }^{29}$ Lihat di dalam Bourgh, "A Symposium on Civil Religion", Sociological Analysis, 1976, 37, hlm. 2
}

batas-batas yang sama. ${ }^{30}$ Perdebatan ini sebenarnya berlangsung lama di dalam berbagai disiplin. Di dalam ilmu politik, ia berkaitan dengan implikasi-implikasi politik dari hubungan gereja dan negara.

Seperti diakui Bellah bahwa istilah agama sipil diungkapkan pertama kali oleh Rousseau, ${ }^{31}$ yang mengemukakan bahwa agama sipil mempunyai dogma sederhana, di antaranya adanya Tuhan, kehidupan yang akan datang, pahala untuk kebaikan dan hukuman bagi keburukan, serta pengucilan terhadap nirtoleransi agama. Gagasan ini lebih mengandaikan hukum alamiah (Natural law), dibandingan dengan hukum agama (Religious law).

Berkaitan dengan persoalan ini, Bellah menanyakan dua persoalan penting, bagaimana agama sipil berkaitan, di satu sisi, dengan masyarakat sipil dan di sisi lain dengan organisasi gereja? Disadari oleh Bellah bahwa pertentangan antara agama dan politik telah melahirkan perdebatan yang tak kunjung usai. Pada abad kesembilanbelas, kelompokkelompok agama dan politik konservatif menyatakan bahwa agama Kristen sebenarnya adalah agama nasional. Beberapa di antara mereka dari masa ke masa dan pada tahun 1950-an mengusulkan perubahan konstitusional yangsecaraeksplisitmengakuikedaulatan Kristus. ${ }^{32}$ Di dalam mempertahankan

\footnotetext{
${ }^{30}$ Dikutip dari John A. Coleman, "Civil Religion," di dalam Sociological Analysis, 31 (Summer, 1970), hlm. 67.

${ }^{31}$ Lihat Bellah, Beyond Belief, hlm. 172. Lihat juga Rousseau tentang agama sipil, yag dirumuskan sebagai: "The Existence of Deity..., the life to come, the happiness of the just, the punishment of the wicked, the sanctity of the social contract dan the laws: these are the positivie dogmas, as for the negative dogmas...(thus he said), I limit them to only one, that is intolerance. Lebih jauh lihat J.J. Rousseau, Social Contract, terj. R. Grimley (ed.), (Oxford: Oxford University Press, 1972), hlm. 49-52.

${ }^{32}$ Bellah, Ibid., hlm. 188. ketegangan antara gereja dan negara
} 
doktrin pemisahan gereja dan negara, penggagas kelompok ini menyangkal bahwa kebijaksanaan nasional secara intrinsik berhubungan dengan agama. Sedangkan kaum Moderat tentang persoalan ini menegaskan bahwa negara Amerika mengambil sikap permisif bahkan mendukung terhadap kelompolkelompok religius, jadi mengutamakan agama tetapi masih tidak melalaikan institusionalisasi positif yang menjadi perhatian Bellah. ${ }^{33}$

Memang kata-kata agama sipil sebagai pengejawantahan dari nilai-nilai agama di dalam kehidupan bernegara tidak diucapkan secara eksplisit oleh para pendiri negara Amerika, namun, jelas untuk tidak mengatakan bukan pengaruh Rousseau, mengemukakan ide-ide yang sama, sebagai bagian dari iklim kultural akhir abad kedelapanbelas, yang ditemukan di antara orang-orang Amerika. Di sini, Bellah mengutip tulisan biografinya Benjamin Franklin:

I never was without some religious principles. I never doubted, for instance, the existence of the Deity; that he made the world and govern'd it by his providence; that the most acceptable service of God was the doing of good to men; that our souls are immortal; and that all crime will be punished, and virtue rewarded either here or hereafter. These I esteemed the essentials of every religion; and, being to be found in all the religions we had in our country, I respected them all, thou' with different degrees of respect, as I found them more or less mix'd with other articles, which, without any tendency to inspire, promote or confirm morality, serv'd principally to

berakar mendalam di dalam sejarah Kristen. Ide tentang negara nonreligius adalah sangat modern dan sangat meragukan. Lihat Bellah, Varieties of Civil Religion, hlm. 5.

${ }^{33}$ Ibid. divide us, and make unfriendly to one another.

Ada beberapa poin yang disebutkan oleh Benjamin Franklin yang sejalan dengan formulaagama sipilnya Rousseau. Dengan ini makin mengukuhkan eksistensi agama sipil sebagai bagian dari cara pandang bapak pendiri Amerika. Bellah melihatnya bahwa posisi seperti ini pada hakikatnya bersifat utilitarian dalam kaitannya dengan agama. ${ }^{34} \mathrm{Di}$ dalam pidato perpisahan Washington aspek ulitariannya sangat jelas:

Of all the dispositions and habits which lead to political prosperity, Religion dan Morality are indispensable support. In vain would that man claim the tribute of Patriotism, who should labour to subert these great Pillars of human happiness, these firmest props of the duties of men and citizen. The mere politician, equally with the pious man ought to respect and cherish them. A volume could not trace all their connections with private and public felicity. Let it simply be asked whre is the security for property, for reputation, for life, if the sense of religious obligation desert the oaths, which are the instruments of investigation in Courts of Justice? And let us with caution indulge the supposition, that morality can be maintained without religion. Whatever may be concedes to the influence of refined education on minds of peculiar structure, reason and experience forbid us to expect that National morality can prevail in exclusion of religious principle.

Tetapi setiap alasan untuk percaya bahwa agama, khususnya ide tentang Allah, memainkan sebuah peranan yang menentukan di dalam pemikiran para

${ }^{34}$ Bellah, Beyond Belief, hlm. 173. 
negarawan Amerika awal. Hubungan yang erat dari gagasan agama dan konsepsi-diri tentang sebuah republik baru seringkali ditunjukkan dari pemunculannya di dalam dokumendokumen resmi awal. ${ }^{35}$ Di sini, Bellah mencontohkan pidato pelantikan pertama presiden Washington pada tanggal 30 April 1789:

I would be peculiarly improper to omit in this first official act my fervent supplications to that Almighty Being who rules over the universe, who presides in the councils of nations, and whose providential aids can supply every defect, that His benediction may consecrate to the liberties and happiness of the people of the United States a Government instituted by themselves for these essential purposes, and may enable every instrument employed in its administration to execute with success the function alloted to his charge.

No people can be found to acknowledge and adore the Invisible Hand which conducts the affairs of man more than those of the United States. Every step by which we have advanced to the character of an independent nations seems to have bee distinguished by some token of providential agensy...

The propitious smiles of Heaven can never be expected on a nation that disregard the eternal rules of order and right which Heaven itself has ordained...The preservation of the sacred fine of liberty and the destiny of the republican model of government are justly considered, perhaps, as deeply, as finally, staked on the experiment instrusted to the hands of the American people.

Jadi, Bellah melihat bahwa dalam menganalisis unsur-unsur agama sipil seseorang bisa meneliti pidato-pidato

${ }^{35}$ Ibid., hlm. 174. pengambilan sumpah kepresidenan Amerika (Presidential Inaugural Addresses). Di samping itu seseorang juga bisa menafsirkan sejarah kebangsaan Amerika. Bellah mengemukakan:

"There are certain common elements of religious orientation that a great majority of American share. These have played a crucial role in the development of American institutions and still provide a religious dimension for the whole fabric of American life, including the political sphere. This public religious dimension is expressed in a set of beliefs, symbols, and ritual that I am calling the American Civil Religion" 36

Namun demikian agama sipil ini bukan pemujaan terhadap bangsa, sebagaimana dituduhkan oleh para pengkritiknya. Dia mengatakan bahwa tradisi sentral dari di dalam agama sipil Amerika bukan sebagai sebuah bentuk dari penyembahan-diri, tetapi sebagai subordinasi bangsa di bawah prinsipprinsip etik yang melampauinya dan di dalam pengertian inilah ia seharusnya dinilai. Dimensi religius kehidupan politik Amerika yang menjadi ciri dari republik kita karena dasarnya dan prinsip yang paling sentral adalah bahwa bangsa ini bukan tujuan tertinggi di dalam dirinya, tetapi berpijak pada pertimbangan transenden dan bernilai sejauh ia mewujudkan sebuah hukum tertinggi. ${ }^{37}$

Sedangkan John A. Coleman melihat bahwa agama sipil adalah seperangkat bentuk-bentuk dan tindakan-tindakan

\footnotetext{
${ }^{36}$ Robert N. Bellah, "American Civil Religions in the 1970's, di dalam Russell E. Richey and Donald G. Jones (ed.)., American Civil Religion, New York: Harper \& Row, 1974), hlm. 255-272.

${ }^{37}$ Bellah, Beyond Belief, hlm. 174. Hukum tertinggi ini menurut Bellah didasarkan pada hukum alamiah klasik dan agama biblikal.
} 
simbolik yang menghubungkan warga negara dan masyarakatnya di dalam sejarah dengan kondisi tertinggi dari eksistensinya. Namun demikian, agama sipil tidak selalu jelas atau biasanya secara jelas dibedakan dengan gereja atau negara. ${ }^{38}$

Jelas, kedua pemikir ini membedakan antara agama sipil dan gereja serta negara. Namun demikian, ketiganya tidak bisa dipisahkan di dalam tingkat abstraksi. Berbeda dengan masyarakat primitif di dalam analisisnya Durkheim bahwa organisasi agama (di dalam Kristen gereja) dan agama sipil tidak bisa dibedakan. ${ }^{39}$ Tampaknya, meskipun Bellah dipengaruhi oleh Durkheim tidak sepenuhnya keduanya menunjukkan kesamaan, selain karena objek kajian berbeda dan rentang waktu yang sangat terpaut jauh memungkinkan hal itu.

Bellah melihat agama sipil bukan penyembahan terhadap bangsa sendiri, namun inspirasinya adalah dari peristiwa yang terjadi di Amerika serikat di antaranya, perjuangan kemerdekaan bangsa Amerika, penghapusan perbudakan, dan penegakan demokrasi, serta untuk mencapai dunia manusia yang tertib..$^{40}$ Pandangan kosmopolitan Bellah ini sebenarnya tidak hanya ingin ditegaskan sebagai bagian dari pengalaman Amerika, tetapi juga bangsabangsa lain di dunia sebagai upaya untuk menghilangkan benturan antara kepentingan-kepentingan yang sering menjadi pemicu konflik.

Hal menarik lain adalah konsep Tuhan dalam agama sipil yang lebih

\footnotetext{
$\overline{{ }^{38} \text { John A. Coleman, op.cit., hlm. } 69 .}$

${ }^{39}$ Dikutip dari Coleman, Ibid.

${ }^{40}$ Lihat Bellah, The Broken Covenant: American Civil Religion in Time of Trial (New York: Seabury Press, 1975), hlm. 170.
}

dikaitkan dengan tatanan, hukum dan hak dibandingkan dengan keselamatan dan cinta. Orang Amerika akan meraih kemakmuran secara politik dengan memegang kepercayaan seperti ini. ${ }^{41}$ Sebagaimana diungkapkan lebih jauh:

Memorial Day observance, especially in the towns and smaller cities of America, is a major event for the whole community involving a rededication to the martyred dead, to the spirit of sacrifice, and to the American vision. Just as Thanksgiving Day, serves to integrate the family into the civil religion, so Memorial Day has acted to integrate the local community into the national cult.Together with the less overtly religious Fourth of July and the more minor celebrations of Veterans Day and the birthdays of Washington and Lincoln, these two holidays provide an annual ritual calendar for the civil religion. The public school system serves as a particularly important context for the cultic celebration of the civil rituals. ${ }^{42}$

Perayaan hari kemerdekaan telah menjadi peristiwa penting untuk menyatukan seluruh warga, sebagaimana peringatan Thanksgiving yang menyatukan sebuah keluarga. Dua perayaan ini berfungsi sebagai perayaan ritual tahunan bagi agama sipil. Menariknya, sekolah negeri berperan sebagai ruang yang penting untuk perayaan kultus ritual sipil ini.

\section{KESIMPULAN}

Secara epistemologis, agama sipil harus dibedakan dengan agama institusional, gereja. Namun demikian nilai-nilai agama terserap di dalam

\footnotetext{
${ }^{41}$ Beyond Belief: Essays on Religion in a Post-Traditional World by Robert N Bellah (New York: Harper and Row, 1970), hlm. 175

${ }^{42}$ Ibid., hlm. 179.
} 
simbol-simbol seperti, seperti pidato pengukuhan presiden, hari-hari besar nasional, tulisan pada makam pahlawan nasional, bendera, dan tugu-tugu peringatan. Jadi agama sipil tersebut agama dimensi religius atau dimensi transendental. Artinya bangsa Amerika melihat makna dan tujuan sebagai bangsa, dari visi transenden.

Dengan penjelasan di atas, dari uraian terhadap ide Bellah, semangat agama sipil itu sendiri bisa diadopsi oleh bangsa ini, sebagaimana sering dikatakan bahwa Pancasila itu sendiri adalah bentuk agama sipil yang diandaikan Bellah, karena memenuhi unsur-unsur yang disebutkan di dalam agama sipil.

Namun demikian, adopsi ini tidak bersifat taken for granted, sebab sejarah dan kultur kedua bangsa ini sangat berbeda. Jika yang pertama nilai-nilai agama yang diserap adalah agama Kristen, sedangkan yang terakhir adalah lima agama yang telah berurat akar selama beberapa abad di tanah air ini. Selain itu, bangsa Indonesia mempunyai nilai-nilai tradisional yang bersifat lokal yang diperoleh dari warisan nenek moyang sehingga keaneragaman ini makin mengkayakan sumber nilai-nilai bagi terciptanya masyarakat sipil yang mengedepankan universalitas nilai dan moral.

\section{DAFTAR PUSTAKA}

Adam, Peter. (ed., et. al.). 1999. Patterns of Religion, Belmont, California: Wadsworth Publishing Company.

Ahmed, Moinuddin. 1994. Religions of All Mankind, India: Kitab Bhavan.

Allen. Rodger Van., ed. 1978. American Religion Values and The Future of America, Philadelphia: Fortres.
Amstrong, Karen. 2014. Fields of Blood: Religion and the History of Violence, London: The Bodley Head.

Bataille, George. 1992. Theory of Religion, terj. Robert Hurley, New York: Zone Book.

Batchelor, Stephen. 1983. Alone with Other: An Existential Approach to Buddhism, New York: Groove Press.

Bellah, R.N. 1982. "Religion and Power in American Today", di dalam The Catholic Theological Society of America.

$2010 . \quad$ "Confronting Modernity: Maruyama Masao, Jürgen Habermas, and Charles Taylor", dalam Varieties of Secularism in A Secular Age, ed. Michael Warner (et. al.), Cambridge: Harvard University Press.

- 1995. The Broken Covenant: American Religion in Time of Trial, Chicago: Chicago University Press.

ed. 1995. Religion and Progress in Modern Asia (New York: The Free Press.

1992. The Good Society, ed. Madsen, Richard/Sullivan, Wiiliam M., Swidler, Ann, New York: Vintage Books.

1989. Afterword, dalam Beyond Individualism, ed. Donald L. Gelpi, Indiana.

1970. Beyond Belief: Essays on Religion in a Post-Traditional World, New York: Harper and Row.

2011. Religion in Human Evolution From the Paleolithic to the Axial Age, Cambridge: Harvard University Press.

1989. "Christian Faithfulness in a Pluralist World", dalam Postmodern Theology, ed. Fr.B. Burnham, San Francisco.

. 1991. "Cultural Barries to the Understanding of the Church and its Public Role," Missiology. 
2000. "Flaws in the Protestant code: some Religious Sources of America's Troubles," Ethical Perspectives.

. 1990. “Leadership Viewed from the Vantage Point of American Culture", di dalam Origins.

1992. Agama Tokugawa, terj. Wardah Hafiz, Jakarta: Gramedia.

dan Philip E. Hammond. 1980. Varieties of Civil Religion, Cambridge: Harper \& Row. 2002. "75 Years", South Atlantic Quarterly, February.

1974. "American Civil Religions in the 1970's, di dalam Russell E. Richey and Donald G. Jones (ed.)., American Civil Religion, New York: Harper \& Row.

1978. "Religious Studies as New Religion" di dalam Jacob Needleman dan George Baker, Understanding the New Religions, New York: The Seabury Press.

Robert N. Bellah and Hans Joas (ed.). 2012. The Axial Age and Its Consequences Edited by Cambridge The Belknap Press of Harvard University Press.

Bloom, Harold. 1992. The American Religion: The Emergence of the PostChristian Nation, New York: Simon \& Schuster.

Broom, Irena. 1996. Religious Diversity and Human Rights, New York: Columbia University Press.

Cannon, Dale. 1996. The Six Ways of Being Religious: A Framework for Comparative Studies of Religion, Belmont, Albany: Wardsworth Publishing Company.

Capps, Walter H. 1995. Religious Studies: The Making of a Discipline, Minneapolis: Fortress Press.

Casonova, José. 1994. Public Religions in the Modern World (Chicago dan London: The University of Chicago Press.
Catherine, L. Albanese. 1999. America and Religion, edisi ketiga, Belmont, CA: Wadsworth Publishing Company.

Coleman, John A. 1970. "Civil Religion" di dalam Sociological Analysis, 31 (Summer).

Comte, August. 1842. Cour de philosophie positive, 6 vol. (Paris: Barchelier.

Connolly, Peter. 1999. Approach to Study of Religions, London dan New York: Cassell.

Copleston, Frederick SJ. 1960. History of Philosophy: Wolff to Kant, London and New Jersey: Search Press and Paulist Press.

Davis, Allen F. dan Harold D. Woodman. 1984. Conflict and Consensus in Early American History, Lexington: D. C. Heath and Company.

Davis, Charles. 1984. Religion and the Making Society: Essays in Social Theology, Cambridge University Press.

Durkheim, Emile. 1976. The Elementary Forms of Religious Life, London: George Allen \& Unwin, Ltd.

Durkheim, Emile. 1944. The Elementary Forms of Religious Life, terj. Karen E. Fields, New York: The Free Press.

Eliot, Charles. 1954. Hinduism and Buddhism: A Historical Sketch, London: Routledge \& Kegal Paul, Ltd.

Farndon, John. 2011. The World's Greatest Idea, London: Icon Books.

Feuerbach. 1957. The Essence of Religion, terj. George Eliot, New York: Harper and Bros.

Foucault, Michel. 1977. Madness Civilization: A History of Insanity in the Age of Reason, terj. Richard Howard, London: Tavistock Publications.

Freud, Sigmund. 1950. Totem and Taboo, terj. James Stranchey, New York: W. W. Nroton \& Co. 
Frohnen. Bruce. 1992. “Robert Bellah and the Politics of "Civil" Religion, dalam Political Science Review, Fall, Vol. 21, No. 1.

1964. Karl Marx and Friedrich Engels on Religion (New York: Schoken Book.
1964. The Future of an Illusion, terj. W. D. Rovson-Scott, edisi revisi, Garden City, N. Y.: Doubleday \& Co. 